\title{
Akad Wakalah Bil Ujrah Dalam Jual Beli Dropship
}

Tugas Mata Kuliah Fiqh Muamalah

Dosen : Ustadz Rachmat Rizky Kurniawan

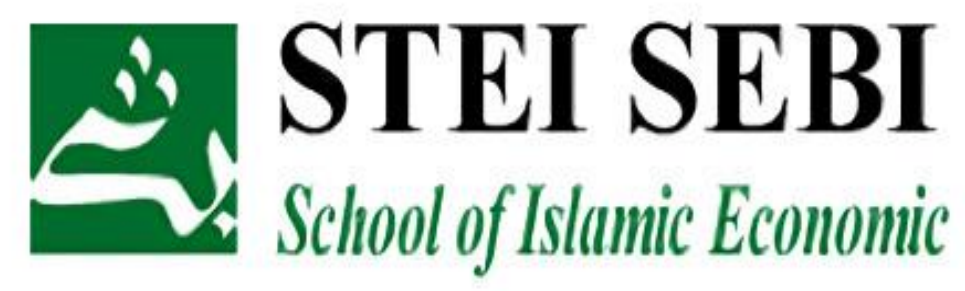

Oleh :

Ahmad Faqih Robbani ( 42104007 )

KELAS A

PROGRAM STUDI HUKUM EKONOMI SYARIAH

SEKOLAH TINGGI EKONOMI ISLAM SEBI ( STEI SEBI ) 2021 


\section{ABSTRACT}

In the teachings of Islam, buying and selling must be in accordance with Islamic law, both in terms of the Shari'a and its pillars. Buying and selling that does not meet the terms and conditions of buying and selling will result in illegitimate trading. Dropship is a product sale that allows dropshipers (resellers) to sell goods to customers by capitalizing on photos from suppliers or stores (without having to stock items) and selling to customers at prices determined by the dropshiper. After the customer transfers money to the dropshipper, the dropshiper pays the supplier according to the dropshiper purchase price (plus shipping costs to the customer) and provides the customer data (name, address, telephone number) to the supplier, because of this data, the supplier will sending goods to consumers, using the name dropshiper. One of the conditions of sale and purchase that must be fulfilled is to have in full the goods to be traded, if these conditions are not fulfilled, then the legal sale and purchase conditions are not fulfilled according to Islamic law. Likewise in dropship buying and selling which is carried out between the seller and the buyer, also must fulfill the conditions as determined by Islamic law.

Keywords : dropship, wakalah bil ujrah.

\section{ABSTRAK}

Dalam ajaran agama Islam, jual beli harus sesuai dengan syariat Islam, baik dalam segi syariat maupun rukunnya. Jual beli yang tidak memenuhi syarat dan rukun jual beli akan berakibat tidak sahnya jual beli yang dilakukan. Dropship adalah penjualan produk yang memungkinkan dropshiper (reseller) menjual barang ke pelanggan dengan bermodalkan foto dari supplier atau toko (tanpa harus menyetok barang) dan menjual ke pelanggan dengan harga yang ditentukan oleh dropshiper. Setelah pelanggan mentransfer uang ke rekening dropshiper, dropshiper membayar kepada suplier sesuai dengan harga beli dropshiper (ditambah dengan ongkos kirim ke pelanggan) serta memberikan data-data pelanggan (nama, alamat, nomer telfon) kepada suplier, karena dengan adanya data ini, maka supplier akan mengirimkan barang kepada konsumen, dengan menggunakan nama dropshiper. Salah satu syarat jual beli yang harus dipenuhi adalah memiliki secara utuh barang yang akan diperjualbelikan, apabila syarat ini tidak terpenuhi maka tidak terpenuhilah syarat jual beli yang sah menurut syariat Islam. Begitu juga dalam jual beli dropship yang dilakukan antara pihak penjual dan pembeli, juga harus memenuhi syarat-syarat seperti yang telah ditetapkan oleh syariat Islam.

Kata kunci : dropship, wakalah bil ujrah. 


\section{DAFTAR ISI}

ABSTRAK

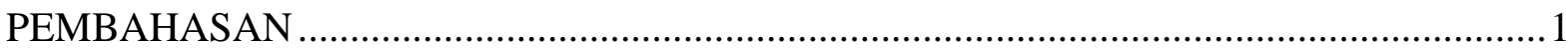

Pengertian Wakalah Bil Ujrah ...................................................................................... 1

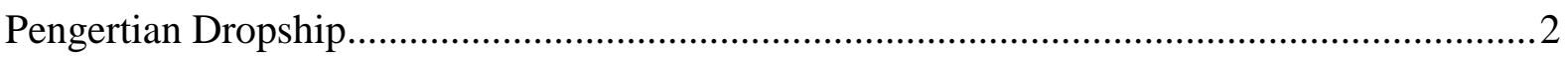

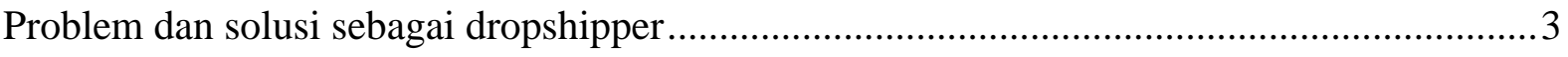

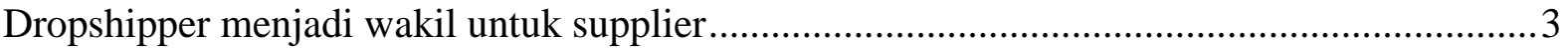

Penggunaan Akad Wakalah bil Ujrah dalam Jual Beli Dropship: .........................................4

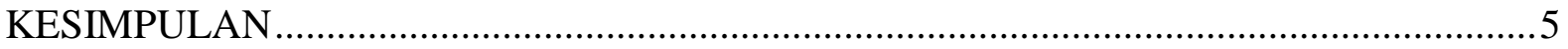

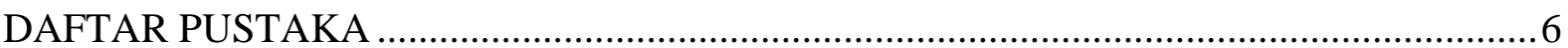




\section{PENDAHULUAN}

Jual beli merupakan suatu kegiatan yang sudah sejak lama dilaksanakan oleh manusia untuk memenuhi segala kebutuhan hidupnya. Jual beli barang merupakan transaksi paling kuat dalam dunia perniagaan (bisnis) bahkan secara umum adalah bagian terpenting dalam aktifitas usaha. Untuk saat ini jual beli yang diterapkan oleh masyarakat tidak seperti jual beli yang diterapkan oleh masyarakat zaman dahulu, karena banyaknya faktor yang mempengaruhinya, salah satunya adalah perkembangan teknologi yang ada. Dalam semua proses bisnis, kepercayaan merupakan kunci utama dalam segala bentuk bisnis, baik dalam lingkungan bisnis online ataupun offline. ${ }^{1}$

Perkembangan teknologi memang sangatlah cepat dan memberi pengaruh signifikan dalam segala aspek kehidupan manusia. Sarana internet sangat membantu manusia sehingga dapat berinteraksi, berkomunikasi, bahkan kemajuan teknologi internet dapat memberikan manfaat sebagai media promosi suatu produk yang efektif dan efisien. Di Indonesia telah mulia berkembang sistem jual beli dengan cara online, salah satunya adalah jual beli dengan sistem dropship. Jual beli dengan sistem dropship dijadikan salah satu alternatif yang dipilih oleh kalangan masyarakat untuk melakukan sistem jual beli online.

Gambaran transaksi sistem jual beli dropship adalah ketika pembeli sudah menentukan barang yang dikehendaki kemudian pembeli mentransfer uang ke rekening dropshiper, kemudian dropshiper membayarkan kepada supplier sesuai dengan harga beli dropshiper (ditambah dengan ongkos kirim kepada pembeli) disertai data dan alamat pengiriman kepada supplier, kemudian barang-barang akan dikirim oleh supplier kepada pembeli. Namun yang menarik, nama pengirim yang tercantum tetaplah nama dari dropshipper. Jadi dalam transaksi ini terdapat tiga komponen yang terlibat, yaitu dropshiper, supplier, dan konsumen. Bila dilihat adanya tiga komponen yang terlibat dalam transaksi ini, maka transaksi ini hampir sama dengan makelar atau samsarah.

Banyak orang yang menggunakan sistem jual beli dropship sebagai pekerjaan sampingan, karena proses dan cara kerjanya yang tidak merepotkan, bisa dilakukan dimana saja dan kapan saja. Sehingga jual beli dropship menjadi salah satu alternatif pekerjaan sampingan di kalangan masyarakat yang dinilai mudah, efektif, dan menguntungkan.

Banyak respon masyarakat tentang jual beli dropship, ada yang setuju dan ada juga yang tidak setuju, yang sangat menjadi pertimbangan adalah dalam hal kepemilikan barang dalam akad jual beli. Kepemilikan barang secara utuh adalah mutlak hukumnya dalam jual beli, karena barang yang diperjualbelikan harus termasuk dalam barang yang dimiliki secara sempurna. Kepemilikan yang sempurna adalah hak milik terhadap suatu benda dan manfaatnya secara bersamaan, sehingga dengan demikian semua hak-hak yang diakui oleh syara $^{e e}$ tetap ada di tangan pemilik. Maka apabila barangnya tidak dimiliki secara sempurna maka barang tersebut tidak dapat ditasharufkan ataupun diperjual belikan.

\footnotetext{
${ }^{1}$ Muhammad. (2004). Etika Bisnis Islam. Yogyakarta: UPP AMP YKPN. hlm. 224
} 


\section{PEMBAHASAN}

\section{Pengertian Wakalah Bil Ujrah}

Pengertian Wakalah Bil Ujrah Secara bahasa, kata al-wakalah atau al-wikalah berarti al-tafwidh yaitu penyerahan, pendelegasian dan pemberian mandat. Contoh kalimat "aku serahkan urusanku kepada Allah" mewakili istilah pengertian tersebut. Jadi yang dimaksud dengan al-wakalah adalah pelimpahan kekuasaan oleh seseorang kepada yang lain dalam hal diwakilkan. $^{2}$

Wakalah bil ujrah yaitu pemberian kuasa dari peserta kepada perusahaan asuransi untuk mengelola dana peserta dengan pemberian ujrah (fee). Dalam kontrak peserta menyetujui kontribusinya dijadikan tabarru' dan digunakan untuk untuk membantu peserta lain yang tertimpa musibah dalam bentuk hibah. Tercantum pula persetujuan kontribusi yang dimasukkan dapat diinvestasikan dan dikelola sesuai dengan prinsip syariah. ${ }^{3}$

Fatwa Dewan Syariah Nasional Majelis Ulama Indonesia Nomor 52/DSNMUI/III/2006 menjelaskan akad wakalah bil ujrah untuk asuransi syariah yaitu salah satu bentuk akad dimana peserta memberikan kuasa kepada perusahaan asuransi dengan imbalan pemberian ujrah (fee). ${ }^{4}$

Adapun pengertian wakalah menurut para ulama sebagai berikut: Imam Taqy al-Din Abu Bakr Ibn Muhammad al-Husaini, wakalah adalah: Menyerahkan suatu pekerjaan yang dapat digantikan kepada orang lain agar dikelola dan dijaga pada masa hidupnya". 5

Hasbi Ash-Shiddiqie, wakalah adalah : Akad penyerahan kekuasaan dimana pada akad itu seseorang menunjuk orang lain sebagai gantinya untuk bertindak" Sayyid Sabiq, wakalah adalah : "Seseorang menunjuk orang lain sebagai pengganti dalam urusan"6

Ulama Hanafiyyah, wakalah adalah : "Seseorang menunjuk orang lain untuk berada di posisinya dalam melakukan tasharruf yang boleh dan jelas, atau menyerahkan tasharruf dan pemeliharaan kepada wakil."7

\footnotetext{
${ }^{2}$ Muhammad Syafi'i Antonio, Bank Syariah Dari Teori ke Praktik, Jakarta: Gema Insani Press, 2001, cet. 1 , h. 120

${ }^{3}$ Andi Soemitra, Bank dan Lembaga Keuangan Syariah, Jakarta: Kencana, 2009, h. 276

${ }^{4}$ Fatwa DSN-MUI No.52/DSN-MUI/III/2006 Tentang Wakalah Bil Ujrah

${ }^{5}$ Abdul Rahman Ghazaly, Ghufron Ihsan, dan Sapiudin Shidiq, Fiqh Muamalah, Jakarta: Kencana Prenada Media Group, 2012, Cet. 2, h. 187

${ }^{6}$ Sulaiman bin Ahmad bin Yahya Al-Faifi, Ringkasan Fikih Sunah, Jakarta: Beirut Publishing, 2014, h. 826

${ }^{7}$ Wahbah Az-Zuhaili, Al-fiqh Wa Adillatuhu, Penerjemah Abdul Hayyie Al-Katani Jakarta; Gema Insani, 2011, h. 476
} 
Ulama Malikiyyah, Syafi'iyah dan Hanabilah, wakalah adalah: "Penyerahan seseorang terhadap sesuatu yang ia berhak melakukannya dimana sesuatu itu termasuk perbuatan yang bisa diwakilkan dalam melakukannya kepada orang lain untuk dilakukan ketika ia hidup", 8

Dari definisi-definisi diatas, dapat diambil intisari bahwa wakalah bil ujarh adalah salah satu bentuk akad dimana peserta memberikan kuasa kepada perusahaan asuransi dalam pengelolaan dana mereka dengan pemberian ujrah (fee).

\section{Pengertian Dropship}

Dropship adalah tehnik pemasaran dimana penjual tidak menyimpan stok barang, dan dimana jika penjual mendapatkan order maka penjual akan meneruskan pesanannya ke distributor/supplier. Lalu supplier akan mengirim barang tersebut dengan menggunakan nama penjual atau dropshipper. Dengan cara begini maka seolah-olah dropshipper memiliki toko pribadi dengan stok barang yang lengkap. ${ }^{9}$

Skema dropship sepertiyang kita uraikan berikut ini; Dalam praktik dropshipyang terjadi adalah dropshipper menerima sejumlah uang dari pembeli, kemudian dropshipper menyetorkan uang kepada pemilik barang. Yang terjadi disini masih dalam taraf, tukar uang dengan uang dengan selisih nominal.

Jika para pebisnis mempraktikan sistem dropship yang bisa jadi dropshipperbertansaksi dengan dropshipper tak terbatas, maka akan menimbulkan melambungnya harga suatu barang tanpa menghiraukan nilai asli barang, dikarenakan setiap dropshipperdiperbolehkanmenaikkan harga sendiri tanpa mengetahui kualitas produk yang dipasarkannya, dan disini pembeli adalah pihak yang paling dirugikan karena membayar mahal atas barang yang bernilai rendah.

Rumitnya proses khiyaratau pengajuan pengembalian barang apabila terjadi ketidakcocokan pesanan, dikarenakan berhubungan dengan banyak pihak yaitu pembeli, dropshipper, pemilik barang, atau bisa lebih dari 3 pihak tersebut, sehingga memungkinkan tidak tuntasnya proses jual beli, dan disini pihak pembeli juga yang dirugikan karena harus dengan terpaksa menerima barang yang tidak sesuai keinginan.

Jika terjadi ketidak sesuaian barang yang dikirim langsung oleh suplier kepada customer, maka disini pihak dropshipperdan customer yang dirugikan, yang mana merusak reputasi tokoonline dropshipper sehingga muncul ketidakpercayaan customer untuk order kembali di toko online dropshipper, dan customer dirugikan dengan menerima barang yang tidak sesuai keinginan.

\footnotetext{
${ }^{8}$ Ibid.

${ }^{9}$ https://pugago.id/pengertian-dropship-dan-sistem-cara-kerja-dropship.php
} 


\section{Problem dan solusi sebagai dropshipper ${ }^{10}$}

Dropshipper tidak memiliki barang, maka akan terkena hadits menjual barang yang tidak dimiliki. Masalah dalam hal ini:

- Dropshipper hanya memajang foto tidak memiliki barang.

- Pengiriman barang dari supplier (owner) bukan dari dropshipper, padahal di sini kondisi barang tidak diketahui.

- Kalau ada keluhan, misal barang cacat, dropshipper tidak mengetahui, padahal pembeli akan menuntut pada dropshipper. Kalau dropshipper lepas tanggung jawab berarti ia zalim karena konsumen hanya tahu beli barang dari dia. Itulah manfaat dalam syariat kita disuruh memiliki barang dahulu.

\section{Solusinya :}

1. Jadi reseller kalau memang punya cukup modal. Sehingga barang dibuat siap stok, lalu bisa dijual dengan harga bebas. Sehingga jika ada pembeli yang memesan cukup menerima permohonan (tidak mengikat). Resikonya, memang siap-siap menerima pembatalan. Kalau tidak punya modal untuk menyediakan barang, jadilah marketer untuk mempromosikan, tidak dropshipper.

2. Menjadi wakil untuk supplier.

\section{Dropshipper menjadi wakil untuk supplier}

Hadits yang mendasari tentang masalah wakil adalah hadits dari 'Urwah ibnu Abil Ja'di AlBariqiy radhiyallahu 'anhu, di mana ia berkata bahwa,

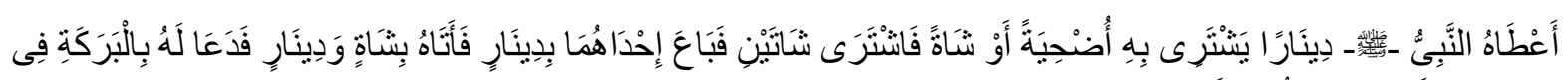

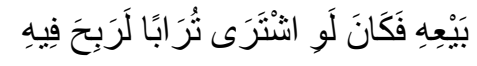

Nabi shallallahu 'alaihi wa sallam telah memberinya satu dinar untuk membeli satu hewan qurban (udhiyah) atau membeli satu kambing. Lantas ia pun dapat membeli dua kambing. Di antara dua kambing tadi, ia jual lagi dan mendapatkan satu dinar. Kemudian ia

\footnotetext{
${ }^{10}$ https://rumaysho.com/25175-solusi-syari-untuk-reseller-dan-dropshipper.html
} 
pun mendatangi Nabi shallallahu 'alaihi wa sallam dengan membawa satu kambing dan satu dinar. Kemudian Nabi shallallahu 'alaihi wa sallam mendoakannya dengan keberkahan dalam jualannya, yaitu seandainya ia membeli debu (yang asalnya tidak berharga sekali pun, -pen), maka ia pun bisa mendapatkan keuntungan di dalamnya. ${ }^{11}$

Hadits ini jadi dalil boleh mewakilkan jual beli pada orang lain.

Hadits ini juga jadi dalil bahwa wakil tidak boleh menyalahi apa yang diminta oleh pihak yang diwakili. Misalnya, wakil tidak boleh menetapkan harga sendiri ketika menjual orang tanpa izin dari supplier.

Syaikh Muhammad Shalih Al-Munajjid membicarakan tentang masalah wakil,

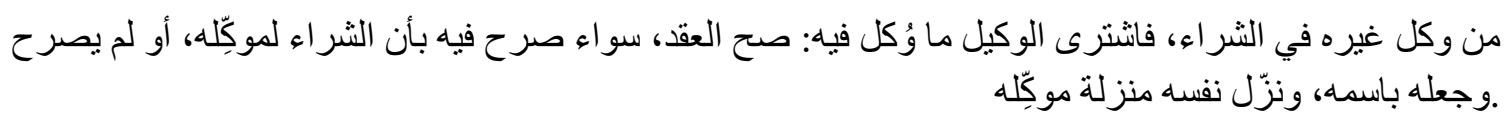

"Siapa yang mewakilkan yang lain dalam membeli, maka si wakil boleh membeli sebagaimana yang diwakilkan untuknya, Akad tersebut sah, terserah di sini secara tegas atas nama yang membeli adalah orang yang ia wakilkan, atau ia tidak menegaskannya dan posisi ia sendiri sudah sebagai wakil." 12

\section{Penggunaan Akad Wakalah bil Ujrah dalam Jual Beli Dropship :}

Jadi wakil dari pembeli, uang diserahkan, dan mendapatkan fee. Statusnya jadi wakalah bil ujrah.

1. Jalin kerjasama dengan supplier. Biasanya dropshipper disuruh menjadi anggota, bahkan ada yang meminta uang keanggotaan.

2. Dropshipper tidak mengapa tak memiliki stok barang.

3. Dropshipper boleh mengiklankan barang dan mendapatkan fee dari situ, baik dengan transaksi ijarah maupun ji'alah, yang keduanya adalah bentuk mengupahi. Ijarah itu mengupahi layaknya pegawai. Ji'alah itu mengupahi dengan melihat target penjualan.

4. Dropshipper boleh menerima pembayaran karena sebagai wakil sama posisinya seperti penjual yang sudah diizinkan.

5. Boleh mengirim barang dari supplier ke konsumen karena sudah ada kerjasama wakalah.

\footnotetext{
${ }^{11}$ (HR. Abu Daud, no. 3384 dan Tirmidzi, no. 1258. Al-Hafizh Abu Thahir mengatakan bahwa sanad hadits ini hasan).

12 (Fatawa Al-Islam Sual wa Jawab, no. 299918)[1]
} 
6. Dropshipper harus siap menerima komplain karena konsumen tahunya bertransaksi dengannya.

Dalam hadits dari 'Abdullah bin 'Amr radhiyallahu 'anhuma dinyatakan,

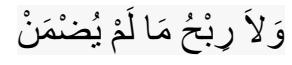

"Tidak boleh ada keuntungan tanpa menanggung resiko."13

Kaidah yang patut diingat pula dan ini menurut ulama Malikiyah ketika membahas masalah pembagian keuntungan dalam syirkah al-'inan (masing-masing memberi modal dan mereka bekerja bersama),

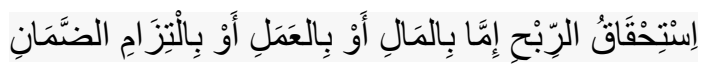

“Orang berhak mendapatkan keuntungan, karena modal, usaha, atau menanggung resiko.” 14

\section{KESIMPULAN}

Dalam transaksi jual beli melalui sistem dropship antara ijab dan qabul tidak dilakukan di tempat yang sama, tetapi melalui media internet. Meskipun demikian transaksi jual beli melalui dropship tetap boleh dilakukan karena pada dasarnya jual beli yang terjadi melalui perantara, baik perantara utusan maupun media internet adalah sah, apabila antara ijab dan qabul sejalan antara keduanya.

Dari penjelasan di atas, dapat dikatakan bahwa jual beli via telefon dan internet adalah dibolehkan. Alasannya adalah: pertama, ia termasuk aspek muamalah yang pada dasarnya boleh, kecuali ada dalil yang mengharamkannya; kedua, bila dilihat dari aspek maqashid asysyariah, di dalam jual beli via telepon dan internet terdapat kemaslahatan, berupa kemudahan transaksi, dan efisiensi waktu. Setiap persoalan muamalah yang di dalamnya dijumpai unsur kemaslahatan, maka itulah yang dituju oleh hukum Allah, kata Izzuddin Abdussalam, tokoh fikh mazhab Syafie ${ }^{15}$ ketiga, lebih dari prinsip kemaslahatan ini, yang tidak kalah penting adalah subtansi makna yang terkandung dalam suatu bentuk muamalah serta sarana yang akan tercapai dan bukan bentuk fomal dari padanya. Kaidah fikih menyebutkan "yang

\footnotetext{
${ }^{13}$ (HR. An-Nasai, no. 4634. Al-Hafizh Abu Thahir mengatakan bahwa sanad hadits ini sahih).

${ }^{14}$ (Al-Fiqh Al-Islami wa Adillatuhu, 4:609)

${ }^{15}$ Mardani. (2011). Hukum Ekonomi Syariah di Indonesia. Bandung: Refika Aditama. hlm. 197.
} 
menjadi patokan dalam setiap transaksi adalah subtansi makna yang dikandungnya serta tujuan-tujuannya, dan bukan pada bentuk formalnya, tidak pula pada lafad-lafadnya".

Segala hal yang menyangkut kenyamanan, keamanan, dan pelayanan sebaik mungkin terhadap konsumen merupakan prioritas bagi para dropshiper. Komplain konsumen atas barang yang dikirim dan tanggung jawab dropshiper atas barang yang dikirimkan. Dropshiper pernah menerima keluhan dari konsumen karena barang yang dikirim tidak sesuai, ada yang rusak, salah kirim atau tertukar dengan konsumen lain, maka dari pihak dropshiper akan menukarkan barang yang tidak sesuai tersebut dengan barang yang sesuai dengan yang dipesan oleh konsumen dan biaya penukaran barang ditanggung oleh dropshiper.

Fenomena praktik transaksi jual beli dropship merupakan transaksi yang dibolehkan, apabila barang yang diperjualbelikan di miliki atau sudah mendapatkan ijin untuk diperjualbelikan, adapun keabsahan transaksi tersebut dapat ditinjau dari aspek adanya kemaslahatan yang besar di dalamnya. Transaksi jual beli dropship yang selama ini beredar di masyarakat merupakan jual beli yang dibolehkan, karena tidak melanggar ketentuanketentuan yang sudah berlaku dalam hukum Islam. Baik dalam segi syarat-syarat jual beli, akad, kepemilikan, terhindar dari gharar, mengandung kemanfaatan, dan lain-lain.

\section{DAFTAR PUSTAKA}

Muhammad. (2004). Etika Bisnis Islam. Yogyakarta: UPP AMP YKPN. hlm. 224

Muhammad Syafi'i Antonio, Bank Syariah Dari Teori ke Praktik, Jakarta: Gema Insani Press, 2001, cet.1, h. 120

Andi Soemitra, Bank dan Lembaga Keuangan Syariah, Jakarta: Kencana, 2009, h. 276

Fatwa DSN-MUI No.52/DSN-MUI/III/2006 Tentang Wakalah Bil Ujrah

Abdul Rahman Ghazaly, Ghufron Ihsan, dan Sapiudin Shidiq, Fiqh Muamalah, Jakarta: Kencana Prenada Media Group, 2012, Cet. 2, h. 187

Sulaiman bin Ahmad bin Yahya Al-Faifi, Ringkasan Fikih Sunah, Jakarta: Beirut Publishing, 2014, h.826

Wahbah Az-Zuhaili, Al-fiqh Wa Adillatuhu, Penerjemah Abdul Hayyie Al-Katani Jakarta; Gema Insani, 2011, h. 476

Ibid.

(HR. Abu Daud, no. 3384 dan Tirmidzi, no. 1258. Al-Hafizh Abu Thahir mengatakan bahwa sanad hadits ini hasan). 
(Fatawa Al-Islam Sual wa Jawab, no. 299918)[1]

(Al-Fiqh Al-Islami wa Adillatuhu, 4:609)

Mardani. (2011). Hukum Ekonomi Syariah di Indonesia. Bandung: Refika Aditama. hlm. 197.

https://pugago.id/pengertian-dropship-dan-sistem-cara-kerja-dropship.php https://rumaysho.com/25175-solusi-syari-untuk-reseller-dan-dropshipper.html 